Kohl: a Journal for Body and Gender Research

Vol. 1, No. 2 (Winter 2015)

\title{
One is Not Born, But Rather Becomes, Joumana
}

\author{
Sanaa Khoury
}


On the back cover of The Third Sex: what Plato told me on his deathbed (Naufal Books, 2015), the publisher is adamant to insert a quote by Paul Auster, which we are to understand as a praise of the book. No doubt, such recognition from a famous American author like Auster is an important marketing strategy for Haddad's latest publication. The author of The New York Trilogy qualifies The Third Sex as "an electric shock of thought." As you flip through more than 220 pages, you attempt to locate the source of that "electric shock." And by the time you turn the last page, after much effort, you might be deluded into thinking that Auster's statement is derisive at best. Or maybe, his perspective suffers from such disconnection with reality that it fails to view any literary or artistic work from the Third World as anything but a dazzling "exotic fruit." Even if the product is painfully shallow, a title that displays the word "sex" and carries the signature of an Arab woman - telling us how lucky and liberated she is - suffices for the Orientalist reader to get shook by lightning.

The title of the book - The Third Sex - carries many false promises. You first imagine that it at least makes allusion to Simone de Beauvoir's seminal work, The Second Sex. But you also expect a new order of things, with Haddad contributing to the fields of sociology and feminist philosophy, or to the theories of gender. The landmarks of this debate would not be easy to map out, especially that the many schools of thought and intellectual currents are interwoven. Some continue what Beauvoir started while others contradict it, starting with Judith Butler's theories, to Arab feminists such as Nawal El Saadawi and Fatima Mernissi, to the tens of current academic publications that attempt to build on the daily struggles of women around the world in order to contribute to a new social and political understanding of feminist writings from divergent perspectives. This is exactly what Haddad does not do. If the human mind can remember Beauvoir's "one is not born, but rather becomes, a woman," then it certainly must remember Haddad's "one is not born, but rather becomes, Joumana" - a statement that the Lebanese poet and translator screams both directly and indirectly throughout her oeuvre.

The Third Sex is the third and final book of a trilogy that started with I Killed Scheherazade (2010), followed by Superman Is an Arab (2012). As with the previous two books, Haddad declares her revolution against the oppressive patriarchal system. Yet, she does so while keeping her hands clean, shielded by layers of gloves. Following the lineage of her published series, the author tends to choose titles that spuriously purvey important philosophies and struggles, only to reveal a content that, at best, reads like a diary, or a collection of scattered personal thoughts about the body, the self, and the world that Haddad draws from her very peculiar feminist view.

Theoretically speaking, the title of the book is quite estranged from its content: it appears to be parachuted from a different field as it abruptly embarks on a journey of self-glorification and praise. When we hear "the third sex" in 2015, we are inevitably reminded of the heated and ongoing debates around the legal and popular terminologies adopted by and about intersex and transsexuals. This is without mentioning the multitude of discourses that attempt to redefine gender identities on the political, psychological, social, and legal levels.

Haddad speaks of The Third Sex as if she somehow invented the term herself, assuring her readers that she is by no means referring to "the third gender that some cultures... have started to recognize" (13-14). Instead, 
her use of the term "wants to transcend the gender and feminist discourse to a humane, comprehensive discourse. It wants to say that the Humanus is the New Gender, and Humanness is the New Feminism (as much as it is the New Morality or the New Political Philosophy or the New Economical (sic) model etc.)" (14). And so, with only the first couple of pages, it becomes easier to detect the conceptual and etymological confusion that the book comprises. In the opening pages, Haddad declares her intention to theorize what she calls "the Humanus human" and the Humanus feminist, despite the fact that most respected theories of gender, old and new, break away from any philosophy that assigns a pre-determined role and identity to a person according to their sex, class, or race.

Haddad devotes her book to conversing with Plato on his death bed. She announces in all seriousness that Plato is willing to hand her over the torch of philosophy so that she can follows his path by developing his thoughts. In the first few pages, Plato admits to Joumana that he was wrong to condition "this Man based on the criteria and hierarchy of my city, while I should have done the opposite. I segregated people in classes, distinguishing between those fit to rule, fit for war, and fit for work. I molded them upon the principle of mutually exclusive powers (either mind or passion or lust), while I should have celebrated their ability to have all three, and more. That is, their ability to be humane" (18). The book, then, paradoxically wants to talk about the third sex, but not "that" third sex. It wants to adopt the humanist philosophy - which Haddad labels as "Humanus" - as a methodology and revoke it at once. It wants to speak about gender from a Humanus perspective by "transcending" gender (11), as the introduction declares. The book "position[s] itself beyond the gender discussion... It means to convey a 'turning of the back' attitude to all existing classifications (biological sex, gender, sexual orientation, sexual identity etc.) and to the exhausting analyses that come with these: analyses that are often preoccupied with putting the specific name on a phenomena or an experience that 'dared' to precede or defy the expected 'diagnosis', that they end up suffocating it and locking it behind the bars of rhetoric, 'justification' and psychological scrutiny. But Humanus doesn't need a validation. Humanus is" (14).

Terminologies are dangerous, but Haddad's book kills them. Its title and argument align themselves with a gender-feminist debate, while raising itself above any "contamination of feminism" at the same time. The Lebanese author thus pursues the path of some influential public figures of the West, from actresses to female writers and singers, who consider it an insult to have their positions labeled as "feminist." Instead, they hide behind a humanist speech of equality between men and women (to which Joumana adds a third sex that she defines according to her innovative vision). They use concepts of traditional masculinity and femininity by trying to harmonize between the two, as if the issue is limited to a struggle between Scheherazade and Shahryar or between Superman and Cat Woman, as the author implied in the first two books of her trilogy. This "Humanus" discourse does not differ in essence from the patriarchal discourse, as it glosses over the contextual specificities of the feminist struggles in their different forms across the world. In the Arab World in particular, talking about female discrimination is not an intellectual luxury or a miserable attempt at theorizing based on Platonic philosophy. To consider that the "human being" is "advanced" in terms of the equality between men and women because both genders are "oppressed" is not methodologically different from equating Palestinians with Israelis. In this example, those banished from their lands are perceived as "contributing" to the occupier's crime, therefore justifying more oppression. A man 
can also be a "victim" of the miserable global economic and political systems, especially if he happens to be poor, homosexual, of color, or deviating in any way from the typical, acceptable, and socially-dictated "catalogue" of manhood. But talking about a "Humanus" who transcends all categories overlooks many forms of gendered injustices that cannot be reduced to equal pay, job opportunities, or education for example. What do we make of child marriages, circumcision, legalizing marital rape, crimes of honor, domestic, and marital violence, when these are all permitted, socially and legally, in many Arab countries? What do we make of the media and the advertising industries that only depict women as sexual objects? What do we make of religious and civil legislations that do not provide any considerable rights for women when it comes to inheritance and custody, among others? And before we even begin to address these, what do we make of the stereotypes attributed to women based on their appearance, interests, and daily life routines, starting from education, to work, to the most mundane acts such as walking down the streets without being subjected to verbal or physical harassment?

Presenting the humane human, or the "Humanus," as a new gender theory may seem a liberating speech on the surface, but in its core, it is nothing but an extension of the inherited patriarchal system that completely excludes women. It is actually a deep misunderstanding of feminism, since the latter does not put women in a hateful confrontation with men. Rather, feminism questions the roles imposed on women by the social, patriarchal, and paternalistic order, and struggles to address and break it.

This conceptual misunderstanding of feminism appears more deeply in Haddad's attempt to create a "different" definition of "the third sex." Haddad does nothing but unearth the same clichéd myth about the "androgynous" being who was split in half to become a male and a female, whereas "the third sex" is a term used legally in some countries to refer to individuals born with male and female sexual organs. According to the Foreign Policy magazine, in 2009, Pakistan approved a law allowing the issuance of identity cards that are not limited to "male" or "female." In 2011, Australia added a box for a third sex on its passports, referred to by an X. In 2013, Germany issued a law allowing parents to remove the indication of sex on birth certificates. In 2014, Facebook enabled more "options" to check in the sex box. In 2014, India recognized the right of individuals to introduce themselves as a third sex, or what is known as the Hijra. Yet, Haddad's book speaks exclusively of herself, which has numerous social and economic privileges. It automatically trivializes the pain of millions of people who are oppressed because they do not fall under the binary of male/female or do not correspond to the framework of learned definitions of femininity, manhood, and the presumed social roles of each sex. Though Haddad openly gives her "blessing" to the right to be different, her stressing on an idea then completely refuting it is customary throughout the eight chapters of her work.

Haddad divides her book according to one pattern that is recurrent with every chapter. It begins with "The Story" that tackles a period in the author's life, or an experience she has had. She then moves to "The Destination," which is a mountain or a labyrinth at times, and a strip club or a jungle at other times. She concludes each chapter with "The Dialogue" between her and the "demons that hiss in [her] head" (50), followed by a bequest from Plato. Despite her prior invitation to free oneself completely from all categories and move towards the "Humane Revolution" (191), Haddad is stuck with the categories that organize the content of her work. She classifies her "Humanus" into seven groups: "The Fighter, the Truthful, the Thinker, 
the Listener, the Compassionate, the Proud, and the Rebellious" (50). She finally concludes with a message to the "youth," inciting them to "dare to change" (190). The book that aligns itself with philosophical thought, riddled with big words such as "gender" and "feminism," appears to be more like the "Secrets of Life and Happiness" lists that spring up like mushrooms on BuzzFeed or in health magazines.

An in-depth reading of the book reveals accounts of Haddad's personal life. In "The Journey of the Proud" (137), for example, she shares how insecure she felt as a child for being endowed with a big nose, clarifying that she got over it because it made her look like the American actress Barbara Streisand. Through a discussion with her "demons," she elaborates on and praises her own outer beauty and the importance of loving one's self. In "The Journey of the Compassionate" (119), she resumes her preaching sermon: not only does she speak of her voluntary work as an adolescent to help the poor, but she also discloses that a boy she had a crush on did not even notice her, because she did not show her "true" self. Once again, Haddad and her "demons" invite us to put "ourselves in the sufferer's shoes for one minute," so that we can understand how "intolerable" his/her circumstances are (132). In "The Journey of the Rebellious" (175), Haddad shares her experience with pornographic literature. She discovered the meaning of sex through her readings of worldwide literature, insisting to let us know how lucky she was. Along the same lines, she concludes the conversation with her "demons" on the necessity of breaking taboos and stripping the self.

While the book is divided into different sections, it orbits the same trajectory - the author's personal experiences, and her conflicts with society. Based on her own experiences, Haddad recreates a philosophy of "the third sex," or the "Humanus," without taking into consideration the methodological dimension or its etymological accuracy. She insists on depriving sharp and politicized feminist challenges of their essence, turning them instead into a narcissistic crisis. She invents new concepts in an effort to prove that "the gender theories are useless" because she, on the individual level, has moved beyond these theories, but only after resolving the issue of her big nose and liberating herself from social masks. When she implies that her path towards "honorable" humanness (190) passes through "reconciling" with her outer appearance as a step towards "liberation," she reemphasizes the patriarchal discourse enforced in mainstream media. It is the same reasoning that constructs the "perfect" woman according to the size of her nose, the measurement of her waist, breasts, and chest, the tone of her voice, the way she moves, and the length of her skirt. Haddad is further alienated from yet another contemporary feminist struggle that works to create and implement alternative definitions to "what a woman should be" by highlighting different bodies that do not conform to imposed standards of beauty (based on race, skin color, weight/size of clothes, age, social class, etc.).

Yet, what if every adolescent girl, who incidentally discovers the existence of those less privileged than her, wanted to produce a brand new feminist theory? What to do if intellect and the media reduced the extensive discussion around feminism to coming to terms with the size of noses? It would probably be fine - everyone has the right to write, express, philosophize, and preach. But it may be useful not to index their book under Philosophy and Feminism when its content does not stray too far from the petty "Characteristics of the Gemini Woman" or "How to Win His Heart in 10 Easy Steps." 